\title{
Competência profissional, recursos políticos e defesa do Jornalismo
}

\author{
Fernanda Rios Petrarca \\ Doutora em Sociologia pela UFRGS. Professora da UFPel \\ f.petrarca@uol.com.br
}

\begin{abstract}
Resumo Este artigo analisa a relação entre a defesa do jornalismo e o uso de recursos políticos. O universo empírico é constituído por jornalistas que participam de entidades que lutam pela "causa dos jornalistas" e a metodologia utilizada foi a investigação das trajetórias sociais, políticas e profissionais das principais lideranças e dos eventos promovidos pelas entidades. Este trabalho demonstra que as manifestações em defesa do jornalismo apontam para uma percepção da profissão que associa "competência profissional" com militância e inserção política. Nesse sentido, a capacidade de converter recursos provenientes da esfera política apresentou-se como um elemento chave na defesa do jornalismo.
\end{abstract}

Palavras-chave: militância; jornalismo; recursos profissionais; recursos políticos.

\section{Introdução}

A relações entre profissão e política são diversas e multifacetadas e A têm se tornado objeto de um conjunto de estudos e pesquisas nas Ciências Sociais. Tais pesquisas, ao mostrarem a imbricação entre estas esferas, trouxeram uma série de problemas e interrogações a serem analisadas, permitindo repensar o tratamento dado até então às profissões e a esfera política ${ }^{1}$. Um desses problemas é a forma como o exercício da militância e da participação política pode se constituir em um recurso nas lutas profissionais por postos e posições e, ao mesmo tempo, em que medida a própria profissão pode se tornar um recurso importante para agir na esfera da política e da militância. A forma como se configuram esses recursos (políticos e profissionais) em situações históricas particulares permite, muitas vezes, compreender os universos profissionais e as concepções de profissão em jogo.

Com base nessa discussão mais geral, este artigo busca analisar a relação entre a defesa da profissão de jornalista e o uso de recursos políticos, obtidos por meio da militância em movimentos sociais, partidos políticos, sindicatos profissionais e entidades associativas. Mais especificamente, trata-se de compreender as manifestações em defesa do jornalismo e as condições de uso e a conversão de capital político como forma de legitimação da regulamentação da profissão. Tal trabalho está inserido numa investigação mais ampla que teve como preocupação central examinar os conflitos em torno da regulamentação do exercí-

1 Sobre a relação entre exercício profissional e engajamento político, no caso da França, pode-se citar o trabalho de Dogan (1999); Offerlé (1999); Sawicki (1999). No Brasil os estudos de Coradini têm destacado as relações estabelecidas no exercício profissional e sua reconversão em recursos eleitorais. Sobre isso ver especialmente Coradini (2001). 
cio do jornalismo e da exigência de critérios formais para o ingresso nesta atividade. Parte-se do princípio que o universo profissional não é apenas um espaço de disputa pelo controle do mercado, como acreditam as perspectivas que analisam os processos de profissionalização pelos quais passam as atividades ocupacionais (Freidson, 1998, 2001), mas é ainda um espaço de confronto para determinar os critérios de pertencimento entre agentes que possuem recursos sociais diferenciados. Nesse sentido, os conflitos em torno da regulamentação do jornalismo são reveladores não só de um confronto pelo monopólio de certos serviços, como também de uma disputa para definir os recursos legítimos para entrada e crescimento na hierarquia do jornalismo. Nessas disputas, os agentes comprometem os recursos que acumularam durante seu trajeto social e profissional e que resultam de sua origem social, formação escolar e inserção em outras esferas de atividade (Boiegol e Dezalay, 1997, Boltanski, 1982, Bourdieu, 1984, 1998). Em tal confronto está em jogo determinadas concepções de jornalismo e sociedade que é preciso levar em consideração.

Diante desta preocupação, na qual se insere este estudo, tomou-se como ponto de partida as mobilizações em torno da exigência da formação superior para o exercício do jornalismo com intuito de examinar o posicionamento das entidades que se manifestaram em defesa da regulamentação do jornalismo e que lutam pelas causas dos jornalistas. Entre tais entidades destacam-se: Federação Nacional dos Jornalistas (Fenaj), Sindicato Profissional dos Jornalistas do Rio Grande do Sul, Fórum Nacional de Professores de Jornalismo (FNPJ) e Sociedade Brasileira de Pesquisadores de Jornalismo (SBPJor). O objetivo principal consiste na análise das concepções de profissão expressas em tais mobilizações e em que medida estas visões sobre o exercício profissional estão relacionadas aos itinerários sociais, profissionais e políticos das lideranças. O recurso metodológico utilizado foi a investigação das trajetórias sociais, políticas e profissionais das principais lideranças e dos eventos promovidos pelas entidades. Nessa investigação, a capacidade de mobilizar diferentes inserções e reconverter recursos provenientes da militância política e partidária para o exercício profissional apresentou-se como um elemento chave na defesa da regulamentação do jornalismo. A idéia central é a de que o militantismo se constitui como um dos principais componentes da defesa do jornalismo e da formação superior. Os efeitos desse militantismo estão mais diretamente relacionados à inserção profissional dos jornalistas e aos usos sociais visando a articulação de diferentes esferas de atuação, sobretudo, o engajamento e o exercício profissional. Assim, um segundo problema perseguido diz respeito às modalidades de exercício profissional do jornalismo e os diversos usos feitos desta atividade.

Nesse sentido, é possível assinalar duas conclusões principais. Por um lado, este estudo demonstra que as manifestações em defesa do jornalismo apontam para uma percepção da profissão que associa competência profissional com inserção política e militância, encaminhando, assim, para um uso militante do jornalismo e da própria formação superior ${ }^{2}$. O jornalismo é visto, ao mesmo tempo, como uma atividade que exige formação específica e como uma atividade militante que requer participação política, inserção em instâncias de mobilização coletiva e atuação em movimentos sociais. Por outro lado, permite mostrar que a militância política constitui-se na principal base de recursos profissionais, uma vez que os jornalistas entrevistados conquistaram postos e galgaram posições jornalísticas em função dos vínculos obtidos mediante do engajamento militante e da inserção simultânea na militância política e no exercício profissional do jornalismo. Portanto, a militância contribui não só para acúmulo de recursos distintos que podem ser mobilizados na defesa de causas profissionais, mas para uma maneira própria de ver o mundo e a própria atividade jornalística.

Para demonstrar tais questões, este texto está dividido em dois momentos principais. Num primeiro momento trata-se de apresentar as concepções e os pontos de vista das entidades de defesa do jornalismo a respeito da regulamentação e da necessidade da exigência da formação superior para o exercício desta atividade. E num segundo momento analisa-se as trajetórias sociais, políticas e profissionais das lideranças das entidades que se manifestaram em defesa do jornalismo. Desse modo, é possível demonstrar em que medida a socialização de tais lideranças e os espaços sociais em que estão inseridos respaldam as concepções associadas à defesa do jornalismo e a um uso particular dessa atividade profissional.

\section{Em defesa do jornalismo, da sociedade e da democracia}

Em 2001, a aprovação de uma liminar que suspendeu a exigência do diploma de nível superior em jornalismo para o exercício da profissão provocou uma série de discussões e debates entre os jornalistas. O pedido de tal liminar, a qual partiu de um promotor orientado pelo jornal Folha de São Paulo, levou diversas entidades e instituições que reúnem a categoria, bem como proprietários e diretores de jornais, a se posicionarem a respeito. Durante esse período, os debates sobre a profissão ganharam visibilidade e temas como liberdade de imprensa, liberdade de expressão, 
democracia, democratização da comunicação, oligopolização dos meios de comunicação, destacaram-se e apareceram associados a essa discussão.

Os jornalistas situados nos espaços dos sindicatos, federações, entidades que reúnem professores de jornalismo e núcleos que visam tratar de especialidades próprias dessa atividade, tais como o núcleo de eco jornalistas, núcleo de assessores de imprensa e o núcleo de jornalistas afro-brasileiros, defendem a exigência do diploma afirmando que é nas universidades que se aprende os fundamentos básicos da profissão, o conhecimento técnico específico para ser jornalista e os requisitos necessários para o exercício de sua função social. Essa função está relacionada a equacionar as demandas sociais, defender a democracia, promover reflexões e contribuir para as mudanças da sociedade. O jornalista é aquele que fornece conhecimento e informação para a sociedade se mobilizar, permitindo aos cidadãos uma posição crítica diante da realidade. Nessa visão, a formação superior em jornalismo interessa não só aos jornalistas, mas à sociedade como um todo, uma vez que é de direito de todo o cidadão uma informação de qualidade, ética e democrática que contribua ao mesmo tempo para promover as modificações necessárias na sociedade, fazendo do indivíduo um cidadão ativo diante da realidade.

[...] a sociedade tem direito à informação de qualidade, ética, democrática. Informação esta que depende, também, de uma prática profissional igualmente qualificada e baseada em preceitos éticos e democráticos. E uma das formas de se preparar, de se formar jornalistas capazes a desenvolver tal prática é através de um curso superior de graduação em jornalismo (...). E não gastamos tantos e tantos anos lutando por isso apenas para ter um diploma, mas sim para garantirmos uma formação realmente de qualidade e ética capaz de dotar o profissional jornalista dos requisitos necessários ao exercício de sua função social (Fenaj, 2002, p. 31 e 36).

O diploma garante uma formação capaz de permitir ao jornalista a aquisição dos elementos necessários para o exercício do seu papel social e, nesse sentido, ele é também de interesse público. Para ser jornalista, além do conhecimento técnico, é preciso ter condições de olhar criticamente os processos sociais, e tal capacidade se adquire na universidade. A universidade conquista sua importância porque nela se desenvolve o espírito crítico, constituindo-se não apenas como palco para aprender a técnica, tão importante para os jornalistas, como também a intervenção social, o desenvolvimento de um comportamento reflexivo diante dos problemas sociais, tais como ques- tões étnico-raciais, discriminação, além da defesa dos valores democráticos. Nessa visão, a universidade não forma agentes capacitados apenas para atuar no mercado, mas o curso de comunicação é apresentado como um espaço de crítica e é isso que faz dele um elemento fundamental na formação do jornalista: "Bons jornalistas são aqueles criados em clima de debates e discussões, são os que têm liberdade para se expressar desde a faculdade, e não os que decoram e repetem infindavelmente conceitos e mais conceitos"3.

Ao mesmo tempo, a defesa pela formação universitária aparece como uma negação ao corporativismo, pois não pretende estabelecer reserva de mercado, nem atingir apenas os critérios de entrada na profissão, delimitando quem deva exercer a atividade, mas propõe-se a ter como principal referência o interesse da sociedade e o desempenho de um compromisso social. A qualificação formal deve ser uma exigência porque permite a construção de notícias com rigor profissional, o que seria fundamental para um mundo mais democrático e justo. Nesse sentido, o ataque ao diploma é apresentado por essas entidades de defesa dos jornalistas como um ataque ao futuro da democracia do país, assim como as liberdades sociais, a cidadania, a imprensa livre, mais do que uma ofensiva aos jornalistas em particular. $\mathrm{O}$ trecho abaixo, extraído do livro: Formação Superior em Jornalismo: uma exigência que interessa a sociedade, organizado pela Federação Nacional de Jornalistas, ilustra essa questão:

[...] É dentro desta batalha maior que a Fenaj, os Sindicatos de Jornalistas em todo o país e a categoria organizada há muito vem lutando, debatendo e construindo o que chamamos de nossa identidade profissional. [...] Não num sentido corporativista, de reserva de mercado, mas tendo, como principal referência, exatamente o interesse público, a função social que envolve a nossa atuação como jornalistas. [...] Por exemplo, defendendo, entre outras questões, a especificidade da profissão, a necessidade de exigência de diploma e de uma graduação de quatro anos, o Programa propõem que só a formação através de um curso superior específico especializado pode tornar consistente a abordagem da multiplicidade dos aspectos filosóficos, teóricos, culturais e técnicos envolvidos na formação dos jornalistas, bem como propiciar que, através da reflexão acadêmica e da prática política e técnica, sejam equacionadas as demandas da sociedade em relação a atuação dos profissionais jornalistas [...] O Programa conclui pela necessidade de que a formação seja teórica, cultural e técnica, possibilitando que, através desta, os jornalistas alcancem a compreensão e a identificação dos fundamen-

3 Trecho extraído de uma apresentação feita por uma professora de jornalismo da Universidade Federal Fluminense durante um seminário, em 12 de julho de 2000, promovido pela Sociedade Brasileira pelo Progresso da Ciência (SBPC) para discutir o ensino de jornalismo. Publicado no site do observatório da imprensa: www.observatorio.ultimosegundo.ig.com.br, acesso em 15 de julho de 2006 
tos éticos prescritos para a sua conduta profissional. Entendam e identifiquem a atitude de cidadania adequada ao exercício da profissão a partir do reconhecimento das expectativas e necessidades da sociedade em relação ao seu papel social.[...] Enfim, estas são apenas algumas amostras de que a defesa da exigência do diploma não é uma questão isolada e muito menos exclusivamente corporativista. [...] E é por isso que a Fenaj, os Sindicatos e a categoria vão continuar lutando pela exigência do diploma, pela regulamentação profissional, entendendo que são batalhas inseridas em lutas maiores, como a luta pela democratização da comunicação (Fenaj, 2002, p. 37-39).

Além disso, o próprio Programa de Qualidade de Ensino de Jornalismo promovido pela Fenaj em parceria com outras entidades como FNPJ e SBPJor, aponta como fundamental a relação próxima que as escolas de comunicação devem manter com setores organizados da sociedade civil que atuem em defesa da democratização da comunicação, contribuindo, assim, para o avanço dos movimentos sociais em direção à cidadania e à construção da democracia.

Desse modo, a defesa do diploma envolve uma luta maior que não pretende se isolar nos debates acadêmicos e entre os próprios jornalistas, mas deseja atingir a sociedade e a busca da democratização da comunicação. Essa luta aparece, freqüentemente, associada a uma crítica ao monopólio dos meios de comunicação, à concentração do capital pela mídia e ao poder que exercem os empresários desse setor sobre a consciência dos jornalistas e de todos os cidadãos. A exigência do título escolar na medida em que impediria o exercício do jornalismo por outros profissionais mais baratos e menos qualificados e de maior interesse das empresas de comunicação estaria contribuindo para permitir ao público uma informação mais independente, crítica e plural, condição que é destacada como essencial para a vida em democracia. Assim, esses jornalistas ao invocarem os valores democráticos e a intervenção na realidade estão contribuindo para politizar o debate.

Esses pontos de vista expressos, no decorrer do debate sobre o diploma, ilustram uma relação entre conhecimento, adquirido nas universidades, e ação, exercida nas suas formas mais variadas como defesa da democratização, crítica ao monopólio da mídia, entre outras já citadas. Essa relação entre conhecimento e ação denota que as discussões não devem ficar circunscritas aos universos profissionais, mas devem voltar-se para a sociedade e, desse modo, nada deve escapar a uma atitude prática na realidade social. Esses jornalistas dedicam-se a uma ação na esfera política, nas mobilizações e manifestações sociais, sem hesitação e acrescidos ainda de uma qualificação especial para isso, adquirida nos centros universitários. Nessa perspectiva, conhecimento e ação não se separam e toda a ação supõe um acesso à realidade. Para as entidades de defesa dos jornalistas o jornalista é um profissional que deve olhar criticamente todos os processos sociais, até mesmo os meios de comunicação de massa, e em função disso ele não tarda a se posicionar contra os donos da mídia se opondo ao controle que exercem sobre os instrumentos de poder social que são os diversos veículos de comunicação.

Com isso, pode-se perceber que predomina, entre esses jornalistas, uma determinada concepção de universidade, escola e profissão que contribuem para fundamentar suas lutas pelo título acadêmico e pela regulamentação do jornalismo. Tanto o jornalismo como a própria universidade em seus pontos de vista devem estar comprometidos com a realidade, envolvendo-se e empenhando-se nas lutas pela democratização de certos setores, pelas liberdades e atuando em defesa da sociedade. A relevância dos cursos está relacionada à sua capacidade de fornecer elementos instrumentais para a ação na realidade social. A formação escolar e acadêmica serve como um uso instrumental, sua valorização está diretamente voltada à possibilidade de oferecer subsídios para atuar tanto em defesa da sociedade, como em defesa do próprio jornalismo.

Tais concepções colocam o jornalista diante de uma missão social e de um papel eminentemente político, na medida em que deve voltar-se para uma atuação na realidade e na sociedade e cuja sua missão é, antes de tudo, uma missão política. Tal apreciação está relacionada a uma caracterização mais geral da cultura política brasileira, para a qual é inconcebível pensar conhecimento e formação acadêmica separado da ação e de uma intervenção social. Essa cultura política, entendida aqui como "fenômeno de sociabilidade política e uma adesão implícita a uma mesma leitura do real" (Pécaut, 1990, p. 184), implica em uma consciência política e uma atuação no plano político. Nesse sentido, a formação acadêmica e o conhecimento, ao permitirem o acesso à realidade, já são, desde o princípio, completamente politizados.

\section{Formação escolar, militância política e inserção profissional das lideranças}

A investigação das trajetórias das lideranças e dos seus itinerários biográficos tem como objetivo mostrar as bases sociais que respaldam a relevância da defesa do jornalismo e que correspondem às modalidades de inserção profissional e a relação que tais jornalistas estabelecem com outras esferas sociais, como a sindical, os partidos políticos e os movimentos sociais. Tratou-se, assim, de pesquisar o passado político-partidário e militante desses jornalistas, suas vinculações com outras 
esferas sociais e a forma de inserção no mercado jornalístico (o início da carreira profissional) ${ }^{4}$. A principal idéia defendida é a de que uma das condições para compreender a defesa do jornalismo e da formação superior é apreender as esferas sociais nas quais estão inseridos os jornalistas e o conjunto de recursos sociais que acumularam.

Nessa análise a inserção simultânea em vários espaços sociais, sobretudo engajamento político e exercício profissional do jornalismo, apresentou-se como um dos elementos fundamentais. Com isso, é possível vislumbrar as características que se destacam entre aqueles que lutam pelo jornalismo, assim como demonstrar os usos que fazem de sua atividade profissional. Para demonstrar a investigação de tais trajetos este estudo analisou as lideranças das principais entidades que se manifestaram em defesa do jornalismo e da formação superior, são elas: Sindicato dos Jornalistas do Rio Grande do Sul, Fenaj, FNPJ e SBPJor ${ }^{5}$. Destas entidades as duas primeiras são sindicais e as duas últimas são entidades de representação dos professores e pesquisadores de jornalismo. Para este texto serão considerados os casos mais representativos do problema analisado.

Ao examinar os trajetos dos jornalistas foi possível identificar que entre a posição social de origem e o momento de ingresso no universo profissional se interpõem uma série de esferas sociais e recursos que contribuem para inserção e ascensão no jornalismo. Entre todos estes, os vínculos obtidos com a militância política assumem importância fundamental, seja esta militância exercida no movimento estudantil, como atividade constante em grêmios, centros e diretórios acadêmicos, seja em partidos políticos e até mesmo associações religiosas e entidades eclesiais de base. Tratados em conjunto, estes jornalistas ingressaram, durante ou após a militância estudantil, no Partido dos Trabalhadores e na esfera sindical (CUT, ...), ocupando, até mesmo, alguns cargos, como diretores e presidentes e trabalhando em campanhas eleitorais na qualidade de jornalistas assessores. A participação política e o exercício da militância são, freqüentemente, apresentados como inerentes ao exercício do jornalismo, tal como eles o concebem, ou seja, um jornalismo de intervenção social e atuação na realidade.

O militantismo, seja na sua forma sindical, seja na de movimento estudantil ou partidário, e em alguns casos vinculados a movimentos religiosos, como grupos eclesiais de base, proporciona uma maneira específica de ver a profissão, mas também de acesso à política, possibilitando, até mesmo, o acesso a certas atividades jornalísticas, como assessorias públicas, assessorias para movimentos sociais, assessorias para partidos políticos e para campanhas eleitorais, bem como para ocupação de cargos na burocracia pública, como diretor de comunicação de empresas jornalísticas públicas e secretário de comunicação. Do conjunto dos casos considerados destacou-se a ocupação de cargos de confiança na burocracia pública como direção da rádio Cultura FM no Rio Grande do Sul, e como secretário da comunicação no período do governo do PT no Estado, assim como candidaturas a prefeito pelo Partido dos Trabalhadores e trabalhos profissionais, na qualidade de técnicos ou assessores, para várias campanhas eleitorais do $\mathrm{PT}$. Além da realização de consultoria e assessoria de comunicação para movimentos sociais e ONGs. Os convites e indicações para realização de tais atividades partiam dos próprios políticos, na maioria das vezes companheiros de militância política partidária ou de colegas jornalistas também membros do partido. Em alguns casos as duas condições (jornalista e militante do partido) convergiam.

Por conseguinte, os cargos conquistados dependem das esferas sociais nas quais estão inseridos e que possibilitam acumular um conjunto de recursos sociais que permitem o acesso a certas posições profissionais. Entre estas esferas sociais destacam-se os partidos políticos, nesse caso o Partido dos Trabalhadores, e o próprio universo profissional, como o espaço das redações jornalísticas como um espaço importante para estabelecer novos vínculos e estreitar os já existentes, resultando no acesso a posições profissionais. $\mathrm{O}$ acesso a estas atividades pode ser encontrado no relato abaixo:

(...) Eu trabalhei muito em rádio, fazendo freela de rádio, mais para movimentos sociais, sindicatos. (...) Também fiz muita campanha eleitoral, ou como voluntária, na maior parte das vezes sem receber nada, mas era um trabalho profissional. (...) P: E como tu tinha acesso a essas atividades? R: São entidades que eu conhecia até porque eu tenho uma militância política, sindical. Sempre tive desde o início, na minha época de estudante eu já estava no sindicato (...). Tinha militância partidária (...) P: E isso te permitia ter acesso a essas atividades de consultoria? R: Eu acho que não só por causa disso, mas, eu acho, a gente não pode ser modesta nessas horas, eu tenho competência, principalmente na área de rádio. Então como eu entendo de rádio, sabia fazer rádio eu então primeiro coloquei meus serviços a disposição voluntariamente, tava se

4 Os dados a respeito das características sociais, do itinerário profissional e da carreira militante foram coletados por meio de entrevistas com os jornalistas considerados como universo de análise.

5 Foram analisadas 14 lideranças: presidente do Sindicato dos Jornalistas do Rio Grande do Sul, sete membros da diretoria de tal sindicato, presidente da Fenaj, secretário geral da Fenaj, dois membros da diretoria da Fenaj, presidente do FNPJ e presidente da SBPJor. Cabe ressaltar que muitas dessas lideranças circulam em várias dessas entidades simultaneamente. 
construindo, não só no movimento sindical. Aí o que acaba acontecendo, um vai dizendo para o outro.

Esse último relato é o de uma jornalista que, durante o trabalho em jornais, como repórter, fazia cobertura de movimentos sociais diversos, o que lhe possibilitava um tipo de acesso específico aos movimentos sociais. Além disso, seus contatos eram reforçados pela intensa militância política, sindical e partidária que exercia desde os tempos da graduação. As militâncias político-partidária e sindical, associadas ao exercício do jornalismo, fornecem os meios necessários para conquistar certos postos. O que é interessante é que as inserções na militância não são vistas como algo acidental ou que desvie o militante da sua profissão, mas ao contrário, são prova de qualidades extraordinárias. A militância política é vista como uma aprendizagem e como uma qualificação que fornece um saber especial sobre o social, uma vez que o jornalista deve ser um militante em todos os sentidos que luta não só pela veracidade das informações que produz no interior das redações, como também luta em defesa da sociedade e da democracia. O relato abaixo de uma das diretoras da Fenaj, do FNPJ, sócia da SBPJor e de outras entidades dedicadas à pesquisa na área da comunicação, tais como Intercom, ilustra tal associação.

No período que eu trabalhei lá, foi o auge das ocupações [de terra] ${ }^{6}$. Daí cobria direto essas matérias (...) Essa área é uma área que eu gosto muito, até pelo fato da minha militância e de tudo isso eu achava que eu cobria bem e eu achava que tinha que cobrir essas coisas. E eu acho melhor quem tem uma visão mais clara em relação a todos os movimentos sociais. Então eu ia direto, não tinha problema nenhum. (...) Quem tem militância política tem muito mais condições, transita bem e consegue explicar bem, fazer bem as matérias de política.

A inserção política e a militância, nesse caso, são vistas como uma forma de contribuir para o exercício de um comportamento crítico, transformador e inquieto. O relato, apresentado a seguir, de um dos jornalistas entrevistados, acerca de como obteve seu primeiro emprego no mercado jornalístico, indica algumas pistas de análise a respeito da importância que assume a militância política também para o acesso ao mercado jornalístico.

$\mathrm{R}:(\ldots)$ um ano depois fui convidado para trabalhar no Diário. O Diário tava se implantando em 1985/1986, aqui. Eu trabalhei no piloto do jornal. O principal responsável para eu entrar no jornal foi o Renan Antunes de Oliveira que na época era coordenador de produção, eu acho, no jornal. E o Renan me levou para fazer sindicato lá dentro do jornal. P: E ele era do sindicato? R: Ele não, ele era, foi da oposição, sempre foi da oposição, mas não era da diretoria do sindicato, mas apoiava e tinha vínculos. E o Renan me levou para sindicalizar as pessoas lá, trabalhar mais no sentido de, ele fez e me colocou na editoria de economia, fiquei, um ano, um ano e pouco trabalhando no jornal até que as coisas se acirraram lá dentro do jornal e aí eles começaram a demitir.

Esse caso merece destaque especial uma vez que seus principais empregos e postos profissionais foram conquistados graças às indicações de colegas do movimento sindical e do PT. Sua atuação foi intensa na coordenação de campanhas eleitorais do PT e quando o PT ganhou as eleições para prefeitura de sua cidade natal, Florianópolis, foi convidado para atuar na qualidade de assessor de comunicação do vice-prefeito que era do partido.

Fiz também assessoria de imprensa para uma faculdade de Direito. Também relações políticas. O diretor da faculdade era advogado do sindicato, me conhecia há anos. Quando ele criou a faculdade de Direito ele me convidou. Fui lá trabalhar. E há sete anos estou dando aula. P: E como tu entraste nessa universidade para dar aula? R: Também por indicação. Maria José, minha ex-namorada, quase mulher, me indicou. O Edelberto que é lá do Sul tava constituindo um curso de jornalismo em Joinvile e tava precisando de alguém que desse aula de políticas da comunicação que era o que eu fazia. Aí fui lá para dar aula de políticas de comunicação, em seguida dei aula de legislação e ética.

O que caracteriza esses trajetos é uma diversidade de vínculos sindicais e políticos, obtidos por meio da inserção em partidos políticos. Os dados acima relatados permitem colocar que a militância exercida no espaço dos sindicatos, dos partidos políticos ou de entidades eclesiais, possibilita não só uma qualificação especial, um saber sobre o social valorizado entre as lideranças, mas também permite o acesso a certas posições e postos dentro do jornalismo. Uma dessas posições ocupadas é a de assessor, consultor, diretor, secretário de instituições públicas. O trabalho de assessoria ou consultoria prestada para campanhas eleitorais, sindicatos, movimentos sociais diversos, bem como o serviço na burocracia pública como secretário de comunicação ou diretor de emissora pública (TVE, por exemplo) é visto como uma forma de exercício profissional pelo conjunto dos jornalistas considerados. A ocupação desses cargos dá-se em nome de uma competência profissional. Entretanto, esses postos são conquistados por meio de uma rede de contatos e vínculos políticos que permitem associar o exercício da profissão ao exercício de uma atividade política. Além disso, esse tipo de uso do jornalismo e a combinação 
entre títulos profissionais e demais títulos obtidos pela inserção militante revelam uma atuação polivalente e uma expansão horizontal ${ }^{7}$ da profissão. Essas questões indicam uma das modalidades de utilização do exercício profissional e do título escolar que aparece associado ao exercício do militantismo.

Como se pôde perceber, nesses casos a acumulação de relações sociais está associada às atividades militantes e políticas e como elas se complementam, assim como na militância estudantil e na partidária, por meio da inserção e da filiação em partidos políticos, de representação categorial, como militância sindical e outros tipos de associativismos. Além dessas inserções, as quais permitem a formação de capital de relações, há também as inserções em espaços como a academia, os jornais e a imprensa de modo geral. Isso quer dizer que a gestão da inserção profissional resulta de uma vasta rede de relações conquistadas.

$\mathrm{Na}$ tentativa de demonstrar como as múltiplas inserções permitem a formação de um capital de relações múltiplas, tomar-se-á um dos casos como exemplar do padrão de trajeto profissional de jornalista e sua vinculação com a esfera política. É o caso do secretário geral da Fenaj, também coordenador do NNDC $^{8}$, professor universitário, membro da diretoria do FNPJ, membro da diretoria do Sindicato dos Jornalistas do Rio Grande do Sul e representante da categoria profissional dos jornalistas no Conselho de Comunicação Social. A relação entre exercício profissional do jornalismo e da política, neste caso, é intensa, o que lhe permitiu chegar a secretário de comunicação e candidato a deputado federal, porém sem sucesso. Sua participação política tem início em grupos e movimentos estudantis, com intensa atividade em um grupo chamado Libelu' ${ }^{9}$. No centro acadêmico do curso de arquitetura, primeira faculdade iniciada, disputou, com sucesso, a presidência do mesmo representando o Movimento Camponês, Operário, Estudantil da Libelu, concorrendo com outras duas chapas, uma delas era do Partido Comunista e a outra da UDS ${ }^{10}$. Nessa época, a Libelu disputava o controle de diversos diretórios acadêmicos no país. Sua entrada nesse grupo ocorreu via um colega do movimento estudantil na Unisinos, universidade onde cursava arquitetura. $\mathrm{Na}$ Libelu afirma ter lido livros clássicos do comunismo e do trotskismo: "Líamos e discutíamos Marx, Lênin e Trotski e todos os comunistas", relembra o jornalista. Nesses grupos, estabeleceu relações com colegas que seriam futuros companheiros de militância partidária e de carreira política. A academia foi o primeiro espaço a aparecer ligado as suas preocupações políticas, conectando assim o engajamento político à vida estudantil. Mais tarde, é a sua vida profissional que aparecerá ligada à militância política.

Ao mesmo tempo em que investia na militância e fazia o curso de arquitetura, começou a atuar em jornais diários da capital fazendo charge e na Cooperativa dos Jornalistas (Coojornal) como ilustrador. Depois de já estar inserido nas redações de jornais, decidiu fazer o curso de jornalismo, iniciado em 1978 e concluído em 1982. Na faculdade de jornalismo da PUC ${ }^{11}$, também atuou no diretório acadêmico na qualidade de presidente e intensificou contatos com professores e colegas que estavam atuando nas redações de jornais. Tais contatos renderam-lhe algumas ofertas de emprego. Uma delas ocorreu por intermédio de um colega que o indicou para uma vaga de diagramador no Correio do Povo. Nesse momento já fazia algumas charges para esse jornal o que lhe possibilitou acumular duas funções no Correio do Povo. Logo depois da falência da empresa Caldas Júnior, a qual publicava tal jornal, e da mudança de proprietários, passou a ser contratado como chargista, abandonando a função de diagramador. A outra oferta de emprego ocorreu por intermédio de um professor da faculdade, também colega de redação do jornal Correio do Povo, que o convidou para dar aulas na PUC, função que desempenha até hoje. Nesse momento, acumulava a função de chargista e de professor universitário, além de intensa atividade política e sindical. Sua atividade sindical, já iniciada desde o momento em que entra para as redações de jornais, intensifica-se quando é escolhido delegado sindical da redação do Correio do Povo e, em seguida, conquista o cargo de vice-presidente do Sindicato dos Jornalistas Profissionais.

A entrada no sindicato e a militância partidária ocorrem simultaneamente, mas os investimentos em cada um desses espaços, como ocupação de cargos e a ampliação da atuação, acontecem em momentos diferentes da carreira. Quando passa a ocupar cargos dentro do sindicato já tinha um longo percurso dentro

7 Essa expressão é utilizada aqui no sentido atribuído por Coradini (2006b) em um dos seus trabalhos sobre o uso de recursos profissionais para fins eleitorais. Ao empregar essa expressão, o autor refere-se aos advogados que combinam o seu exercício profissional com outros títulos profissionais, como uma forma de "expansão horizontal" da profissão. Uma das maneiras de ampliar a atuação é por meio das assessorias em diferentes esferas, com destaque para organismos públicos.

8 Fórum Nacional pela Democratização da Comunicação.

9 Abreviação de Liberdade e Luta a Libelu representava uma corrente trotskista do movimento estudantil. Formada, principalmente, por estudantes universitários e secundaristas tornou-se uma das principais organizações de articulação do movimento estudantil nos anos 1970 . A Libelu nasceu da OSI (organização socialista internacional) e teve como berço a Universidade de São Paulo (USP). Para disputar o diretório acadêmico central da USP alguns integrantes da OSI formaram a chapa Liberdade e Luta. Assim a Libelu tornou-se uma tendência que atraía milhares de estudantes.

10 Sigla de União Democrática Socialista, criada em 1945, em São Paulo, por socialistas opositores ao PCB.

11 Pontifica Universidade Católica do Rio Grande do Sul. 
do PT. Sua primeira presidência no sindicato, ocorreu em 1989 quando o PT venceu as eleições municipais e toda a diretoria do sindicato dos jornalistas foi convocada para organizar a assessoria de comunicação da prefeitura. Nesse momento, de vice-presidente passa a assumir a função de presidente. Foi diretor do Sindicato dos Jornalistas do Rio Grande do Sul por três gestões. Desse modo, é possível perceber um processo de acumulação e ampliação das esferas de atuação.

$O$ ingresso em um curso de graduação em jornalismo ocorreu no mesmo período em que rompeu com a Libelu para entrar no PT, momento em que esse foi criado em Porto Alegre, e abandonou definitivamente a faculdade de arquitetura. A divergência interna na Libelu sobre a possibilidade de integrar um novo partido o fez romper com o grupo e aderir a um verdadeiro partido operário, como ele mesmo definiu em entrevista. Apesar de continuar na direção de centros acadêmicos é possível perceber uma passagem quase imediata da militância estudantil para partidária. Esse jornalista começa na militância estudantil, passa a investir no partido e, aos poucos o movimento estudantil é substituído pelo movimento sindical.

A vida acadêmica desse jornalista, na graduação ou na pós-graduação, tem um sentido de militância permanente. Alguns anos após a conclusão do curso de graduação, em 1984, ingressou no mestrado de sociologia da UFRGS, curso que não concluiu em função da intensa atividade partidária, sindical e profissional nos jornais da capital. A entrada no mestrado foi motivada por um conjunto de amigos, muitos deles do PT, que lá estavam e porque na sua visão era um lugar que se fazia uma leitura sistemática de teoria, possibilitando organizar e sistematizar um debate que fazia ideologicamente na militância. Segundo ele, por meio do curso pode "estudar Marx de uma maneira mais organizada e crítica". Depois desse mestrado, esse jornalista iniciou o mestrado em Comunicação na UFRGS e, atualmente, está concluindo o mestrado em Comunicação na PUC. Sua experiência de militante estimula não só sua vida acadêmica como toda sua vida profissional.

A entrada no curso de graduação em jornalismo, segundo ele, representava uma extensão de sua militância. Em função de já estar atuando em jornais e fazendo militância, afirma ter optado pelo curso de jornalismo para "transformar o país e reformar o mundo", razão pela qual também atua na política e continua no jornalismo. Ele afirma ainda ter encontrado as motivações necessárias para entrada no jornalismo na militância estudantil, a qual permitiu desenvolver, de forma organizada, uma "crítica social” já manifestada na infância e na juventude. A apresentação dos motivos que o levaram a escolher o jornalismo torna-se um meio apropriado para integrar seus interesses políticos dentro da sua futura vida profissional. A escolha aparece elaborada em ligação com sua sensibilidade política, o que contribui para reforçar ainda mais o seu engajamento.

Além disso, na sua visão, o papel do jornalismo e do jornalista é intensificar a "esfera pública", proporcionar as populações excluídas e de baixa renda as mesmas informações que são destinadas a outros grupos sociais e não propor jornais especializados, jornais que seriam, em suas palavras, "de classe, segmentados". Assim, o jornalista estaria cumprindo o seu papel de contar a história cotidiana a todos os segmentos sociais, selecionando o que é de "interesse público" nessa história, aquilo que interessa à população como um todo. Isso demonstra uma definição militante das próprias competências jornalísticas e a reconversão de saberes incorporados pela experiência política em um saber fazer jornalístico.

Porém, os significados atribuídos ao passado e ao próprio exercício do jornalismo dependem da interseção com as esferas às quais estava vinculado. Desse modo, a inserção na militância estudantil, partidária e sindical cria as condições para essa percepção, além de possibilitar a conquista de novas posições e de cargos, ampliando, assim, as esferas de atuação. O militantismo, nesse caso, estudantil, partidário e sindical, contribui não só para formação de uma rede de relações, que podem ser mobilizadas em diversas situações, mas também para uma visão de mundo militante (Gaxie e Offerlé, 1985; Coradini, 2001). Assim, ele orienta subjetivamente as esferas de sua vida pelos seus engajamentos.

Esse caso representa uma modalidade de associação de recursos em que a atuação partidária e sindical ocorre simultaneamente aos investimentos no jornalismo, possibilitando uma interferência nesses dois espaços. Os exemplos dessas interferências podem ser encontrados nas diversas greves da categoria do qual participou, nos cargos políticos que ocupou na qualidade de jornalista e na participação da Cooperativa dos Jornalistas, compondo a última chapa (petista) vencedora das eleições na década de 1980 a qual levaria ao racha definitivo da Coojornal. O fim da Coojornal foi provocado por uma forte tensão entre aqueles que representavam o grupo fundador, e que pensavam a cooperativa como um empreendimento jornalístico, e aqueles que pensavam o jornal como um empreendimento político, representado pela chapa formada por militantes do PT.

No que diz respeito aos cargos políticos que ocupou, esse jornalista foi Secretário de Comunicação do governo do estado de 1995 até 1998 pelo PT. Além desse cargo, nas eleições de 1994 candidatou-se a deputado federal pelo $\mathrm{PT}$ reconvertendo assim os recursos políticos em recursos eleitorais, mas como não se elegeu, o partido convidou-o para administrar a pasta de comunicação do estado. Nessa mesma época, compôs as chamadas executiva e executivinha do partido que consistem em grupos de cinco pes- 
soas definidas pelo partido que recebem salário para ocupar tal função.

Atualmente, além de professor, esse jornalista atua na secretaria da Fenaj, na diretoria do Sindicato dos Jornalistas do Rio Grande do Sul, coordena o Fórum Nacional pela Democratização da Comunicação, compõem a diretoria do FNPJ e representa os jornalistas no conselho de comunicação social. A sucessiva ocupação de posições de lideranças e de cargos em organizações sindicais, associativas e políticas ocorre simultaneamente ao investimento na carreira acadêmica. Esses postos adquirem um duplo sentido, na medida em que esse jornalista apresentaos constantemente como uma atuação profissional e política. Apesar de tratar-se de cargos políticos que dependem de certo vínculo partidário, essas atuações são percebidas como atuações jornalísticas que permitem colocar o conhecimento que ele tem do jornalismo a serviço da comunicação e da política. As atividades políticas são definidas como um prolongamento da atuação profissional e essa última, por sua vez, é percebida como completamente política, visto que o próprio exercício do jornalismo é concebido como uma atividade militante, que implica intervenção e de atuação diante da realidade. Os cargos e as atividades que desempenha atualmente, como representante de entidades da categoria e de movimentos sociais como FNDC, entre todos os outros, representam a possibilidade de desempenhar esse duplo papel, promovendo políticas de comunicação e colocando o conhecimento jornalístico a serviço da população.

Em síntese, este trajeto caracteriza-se por um conjunto de investimentos simultâneos no jornalismo, na militância estudantil, no Partido dos Trabalhadores e no Sindicato dos Jornalistas do Rio Grande do Sul. Os contatos proporcionados por tais investimentos renderam-lhe uma candidatura e o cargo de secretário estadual de comunicação, além de lhe possibilitarem a liderança sindical. A inserção militante, partidária e sindical permite acumular um conjunto de recursos que podem ser usados para diversificar os espaços de atuação jornalísticos.

A ligação entre a esfera profissional e aquela do engajamento aparece claramente tanto no que diz respeito aos recursos que são convertidos para ampliar os espaços de atuação profissional, como nos aspectos subjetivos que permitem estabelecer uma conexão entre esses espaços ${ }^{12}$. Ao longo da entrevista realizada pra este estudo, ele não cessou de colocar que seu trabalho e seu engajamento político fazem parte de um todo e que não estão separadas, apesar de seu constante esforço para controlar as interferências que podem ocorrer entre o jornalismo e a política. Assim, a imbricação desses espaços dá à sua ação um sentido.
Esse jornalista procura apresentar uma coerência em seus relatos entre sua atuação profissional e sua atuação política. A preocupação dessa coerência é central para ligar subjetivamente essas esferas que, à primeira vista, não tem laços comuns.

Assim, percebe-se que entre a posição social de origem e o momento de ingresso no jornalismo mesclam-se um conjunto de relações e vínculos com esferas sociais diversas. De todas essas esferas, a esfera político-partidária assume importância fundamental, pois a proximidade com o universo político-partidário e militante gera um capital, para o jornalista, de relações sociais que pode ser reconvertido em capital político, manifestado pela filiação a partidos e ocupação de cargos políticos (assessor, diretor de emissora pública), mas pode também ser reconvertido para possibilitar a atuação dentro do jornalismo. Esses dados permitem indicar, ainda, que há um uso simultâneo de recursos acumulados na esfera da militância estudantil e da político-partidária, assim como daqueles adquiridos nas universidades pela formação em cursos na área de jornalismo (mestrado e doutorado). $\mathrm{O}$ que respalda uma determinada concepção acerca do diploma é a diversidade de recursos acumulados e a intensa proximidade com o universo da política, uma vez que a defesa do jornalismo como uma forma de intervenção social não está separada dos usos que esses jornalistas fazem do título e dos recursos que permitem a valorização. A análise dos processos de socialização das lideranças permite mostrar de que forma a inserção na esfera da política e o acúmulo de recursos proporcionados por tais inserções contribui para determinadas percepções acerca do diploma e da regulamentação profissional.

\section{Conclusão}

Este artigo procurou mostrar, primeiramente, que a defesa da regulamentação do jornalismo e da exigência da formação superior não se constituem apenas como uma estratégia para controlar o mercado de trabalho mediante a competência técnica. Ao contrário do que se possa pensar, o diploma não se constitui como uma garantia para manter o monopólio do conhecimento especializado, mas para permitir a mobilização política e o desenvolvimento do "comportamento crítico". Em segundo lugar, demonstrou que nas lutas profissionais por classificação e imposição de princípios estão presentes esquemas de percepção e definição da condição profissional engendrados em um papel político do jornalista. Tal definição e tais esquemas de percepção resultam tanto da história da 
profissão no Brasil e da importância dos títulos escolares nessas condições, como também do processo de socialização das próprias lideranças, das experiências que vivenciaram antes e durante a inserção nas entidades associativas e de representação. O que se observa é que o desenvolvimento da profissão de jornalista revela um verdadeiro trabalho social em colocar o jornalismo a serviço da construção política da sociedade, da nação e do Estado Nacional. De maneira muito diversa, sucessivas gerações de jornalistas que defenderam a regulamentação da profissão não cessaram em fazer do jornalismo uma forma de colocar o seu conhecimento, os seus títulos escolares e acadêmicos, a serviço de causas definidas na esfera política ${ }^{13}$. Contudo, essa não é uma peculiaridade do jornalismo, uma vez que é comum entre as camadas escolarizadas no Brasil colocar o conhecimento especializado a serviço da construção da nação (Pécaut, 1999).

Nesse texto tratou-se de dar destaque para a forma como as classificações profissionais estão relacionadas com os recursos sociais que as respaldam, o que torna possível relacionar as lutas pela classificação legítima com as esferas de atuação em que os jornalistas estão inseridos e com o engajamento político, associativo e sindical. A conclusão mais geral é a de que por meio de exame das manifestações dos jornalistas e de suas trajetórias interessa, particularmente, a relação entre recursos sociais e esferas de atuação.

Ao longo desse texto demonstrou-se que, as manifestações das entidades de representação da categoria e a própria defesa do diploma e os outros critérios de regulamentação do jornalismo, convergem no sentido da negação do exercício profissional em sua definição estrita e formal. O sentido da defesa do diploma aparece associado não a uma ideologia meritocrática, mas à possibilidade de formação de uma consciência crítica e de transformação social, bem como à idéia de uma utilidade pública que interessa à sociedade. Assim, para os jornalistas vinculados a tais entidades, é pela ação de mudança que a formação superior provoca que a sua validade está garantida. A defesa da profissão e o sentido que se atribui a ela remete à atuação em outras esferas sociais e a outros princípios que legitimam o trabalho profissional e que não estão vinculados ao exercício profissional stricto senso, mas a possibilidade de intervenção diversa.

As mobilizações em torno de determinadas definições do jornalismo e da própria universidade traduzem um processo de politização dessa profissão. Dessa forma, a defesa do diploma não é somente uma forma de controle de entrada e de exercício do jornalismo como é também um instrumento de politização, na medida em que permite o desenvolvimento de um comportamento político, manifestado na crítica social, no combate ao monopólio das empresas de comunicação e na luta por valores democráticos. Por conseguinte, a defesa do diploma surge como um recurso cuja utilização situa-se em dois planos. No primeiro plano, a defesa de um princípio de classificação baseado em títulos universitários como critério de ingresso no mercado jornalístico. No segundo plano o diploma, aparece como uma arma contra a grande imprensa e contra os interesses do capital e dos donos dos meios de produção, como demonstram os relatos dos dirigentes das entidades analisadas. A defesa do diploma pelas entidades que visam garantir a produção do diploma (Fórum de Professores de Jornalismo) e a daqueles que lutam por uma relação segura entre diploma e ocupação de cargos (sindicatos da categoria e a Fenaj), não implica abstenção política, muito pelo contrário, oferece um argumento nessa batalha. O jornalista aparece como um profissional extremamente engajado e comprometido com a sociedade e suas lutas devem estar voltadas para a defesa de um cidadão atuante e crítico que se mobiliza diante dos problemas sociais.

O exame do discurso de defesa da valorização do título acadêmico e sua relação com os itinerários dos jornalistas envolvidos em sua defesa, permitiram mostrar que o que caracteriza o trajeto dessas lideranças é a combinação de várias militâncias, como a estudantil, a sindical, a de atuação em partidos políticos, em movimentos sociais como o Fórum pela Democratização da Comunicação e em alguns grupos específicos como Fórum Nacional de Professores de Jornalismo. Para tanto, o elemento mais relevante consiste na maneira como as lideranças relacionam a escolarização e a formação acadêmica com militância em diferentes esferas sociais. Nesse sentido, os jornalistas, líderes de entidades profissionais, fazem de sua formação acadêmica um instrumento para atuar na esfera da política, seja na manifestação em prol da democratização da comunicação, seja na atuação em partidos políticos e na inserção na burocracia pública. Destarte, seus títulos adquirem valor pelo conjunto de recursos que acumularam fora da esfera escolar, sobretudo na esfera da militância política, e que são reconvertidos para atuação no jornalismo.

Por meio da associação da formação escolar com os investimentos militantes; obtém-se como resultado a ocupação de postos diversos em assessorias para partidos, em assessorias públicas, em universidades. Pode-se, assim, perceber que a militância política predispõe os jornalistas a uma concepção política do título escolar e da profissão. Além dessa predisposição, a militância funciona como um recurso nas lutas pela valorização 
do título acadêmico e da atividade profissional. Assim, a defesa do diploma e do jornalismo constitui uma forma de reconverter a formação profissional para atuação em diferentes esferas sociais, sobretudo a esfera política. A forte socialização política dessas lideranças e os engajamentos simultâneos ao jornalismo constituem um dos elementos principais que fundamentam a defesa do diploma e a possibilidade de fazer deste um recurso para atuar em outras esferas sociais. O jornalismo, cada vez mais, caracteriza-se como um espaço de reconversão de recursos diversos em recursos profissionais, permitindo, assim, ampliar as esferas em que é possível intervir em nome da profissão.

\title{
Referências
}

BOIGEOL, Anne; DEZALAY, Ives. De l'agent d'affaires au barreau: conseils jurudiques et la construction d'un espace professionnel. Genèses, n. 27, p. 49-68, juin, 1997.

BOLTANSKI, Luc. Les Cadres. La Formation d'um Groupe Social. Paris, Les Éditions de Minuit, 1982.

BOURDIEU, Pierre. Homo Academicus. Paris, Editions de Minuit, 1984. trand Brasil, 1998.

O Poder Simbólico. Rio de Janeiro. Ber-

CORADINI, Odaci Luiz. Em nome de quem? Recursos sociais no recrutamento de elites políticas. Relume $\mathrm{Du}-$ mará, Rio de janeiro, 2001

Representação Profissional e Elites

Políticas no Período Recente. Política e Sociedade. Revista de Sociologia e Política, v.5, n. 9, out. 2006a, p. 123-161.

Relações Profissionais e Disputas

Eleitorais. In: BARREIRA, C; PALMEIRA, M. Politica no Brasil. Visões de Antropólogos. Relume Dumará, Rio de Janeiro, p. 267-297, 2006b.

DOGAN, Mattei. Les Professions Propices à la Carrière Politique ; osmoses, filières et vivieres. In: OFFERLÉ, M. (dir.). La Profession Politique: XIXe. Siècles. Paris: Belin, 1999.

FEDERAÇÃO NACIONAL DOS JORNALISTAS (Org.). Formação Superior em Jornalismo: uma exigência que interessa a sociedade. 2. ed. Florianópolis, 2002.

FREIDSON, Eliot. Renascimento do profissionalismo. São Paulo, Edusp, 1998.
. La Teoria de Las Profesiones. Estado Del Arte. Perfiles Educativos. Universidad Nacional Autônoma de México, 23, n. 93, p. 28-43, 2001.

GAXIE, Daniel; OFFERLÉ, Michel. Les Militants Syndicaux et Associatifs au Pouvoir? Capital Social Collectif et Carriere Politique. In: BIRNBAUM, Pierre (dir.). Les Élites Socialistes au Pouvir - 1980-1985. Paris, Press Universitaires de France, p.105-138,1985.

OFFERLÉ, Michel. Professions et Profession Politique. In: OFFERLÉ, M. (dir.). La Profession Politique: XIXe. Siècles. Paris: Belin, 1999.

PASSY, Florence. Interactions Sociales et Imbrications des Sphères de Vie. In: FILliEUlE, Olivier (Org.). Le Desengagement Militant. Paris. Edition Belin, 2005, p. 111-130.

PÉCAUT, Daniel. Os intelectuais e a politica no Brasil. Entre o povo e a nação. São Paulo, Ática, 1990.

PETRARCA, Fernanda Rios. O Jornalismo como Profissão: recursos sociais, titulação acadêmica e inserção profissional dos jornalistas no Rio Grande do Sul. 2007, 308 f. Tese (Doutorado em Sociologia) - Programa de Pós Graduação em Sociologia, UFRGS, Porto Alegre, 2007.

SAWICKI, F. Classer les hommes politiques. Les usages des indicateurs de position sociales pour la compréension de la profissionalisation politique. In: OFFERLÉ, M. (dir.). La Profession Politique: XIXe. Siècles. Paris: Belin, 1999.

\section{Professional competence, political resources, and a defense of Journalism}

\begin{abstract}
This work analyzes the link between the defense of journalism and the use of political resources. The empirical universe was formed by journalists who are part of entities that fight for the "cause of the journalists". The article also analyzed the social, political and professional path of the main leaderships and the meetings promoted by the entities. This study shows that the demonstrations in defense of journalism point to a perception of the profession that associates "professional ability" with political insertion and activism. In fact, the capacity to organize different insertions and to reconvert resources proceeding from the political sphere was presented as a key element in the defense of journalism.
\end{abstract}

Key-words: militancy; journalism; professional resources; political resources. 